\title{
EFFECTS OF EXPERIMENTAL POOL LEVEL REDUCTION ON Phylloicus pulchrus (TRICHOPTERA: CALAMOCERATIDAE) FEEDING AND CONSPECIFIC BEHAVIOR FROM A TROPICAL RAINFOREST STREAM
}

\author{
EFECTO DE REDUCCIÓN EXPERIMENTAL DE POZAS SOBRE LA ALIMENTACIÓN \\ Y COMPORTAMIENTO CONESPECÍFICO DE Phylloicus pulchrus (TRICHOPTERA: \\ CALAMOCERATIDAE) DE UNA QUEBRADA DE BOSQUE TROPICAL LLUVIOSO
}

\author{
Limarie J. Reyes-Torres@ and Alonso Ramírez (D)
}

\begin{abstract}
Increases in drought occurrence and persistence around the world prompts to the understanding of their effects on natural populations and ecosystem functioning. The main result of drought on streams is the fragmentation of stream ecosystems into isolated pools as streamflow and water depth decrease. There are limited studies on caddisfly response to reduced water levels and their effect on ecosystem functioning. The goal of this study was to evaluate how reductions in water levels, similar to those associated with droughts, influence feeding and conspecific behavior of Phylloicus pulchrus. Laboratory experimental pool reductions, simulating the natural conditions of the species in the El Verde Field Station, Luquillo Experimental Forest, were carried out for two weeks. Four rectangular plastic aquaria were filled to one third with stream water that was maintained aerated. Ten circular plastic chambers (with screen windows) with Guarea guidonea senescent leaves were placed inside each aquarium. Two stream pool levels (normal and low) were simulated with two treatments (experimental and control). Experimental chambers $(\mathrm{n}=20)$ contained fourth instar larvae $(n=80,40=$ normal, $40=$ low) while control chambers $(n=20)$ did not. The effect of pool level reduction on leaf mass loss, aggressive interactions between larvae ( $>25 \%$ of their cases removed), and larval mortality were assessed. Reductions in pool level increased leaf mass loss (ANOVA: $F=5.17, p<0.05$ ), larval aggressive interactions (Chi square: $x^{2}=6.24, n=80, p<0.05$ ), and larval mortality (Chi square: $\mathrm{x}^{2}=4.51, \mathrm{n}=80, \mathrm{p}<0.05$. This study shows the early response of a tropical caddisfly to an abiotic cue of a drastic environmental change. This research contributes to our scarce knowledge on caddisfly larvae leaf litter processing behavior during early stages of water reductions, such as those caused by droughts.
\end{abstract}

KEY WORDS: caddisflies; Phylloicus; water level reduction; leaf litter processing; tropical streams; Puerto Rico

\section{RESUMEN}

Aumentos en la ocurrencia y persistencia de sequías alrededor del mundo estimulan el entendimiento de sus efectos en las poblaciones naturales y funcionamiento de los ecosistemas. El principal resultado de las sequías en los ríos es la fragmentación del ecosistema riverino en pozas aisladas, a medida que el flujo y la profundidad del agua disminuyen. Hay estudios limitados sobre la respuesta de los tricópteros a reducciones en niveles de agua y su efecto en el funcionamiento del ecosistema. El objetivo de este estudio fue evaluar cómo reducciones en los niveles del agua, similares a las asociadas con sequías, influencian la alimentación y comportamiento conspecífico del Phylloicus pulchrus. Reducciones de pozas en laboratorio simulando condiciones naturales fueron empleadas por dos semanas. Cuatro acuarios plásticos rectangulares fueron llenados a una tercera parte con agua aireada de la quebrada. Dentro de cada acuario se colocaron diez cámaras plásticas circulares (con aperturas de malla) con hojas senescentes de Guarea guidonea. Se simularon dos niveles de pozas (normal y bajo) con dos tratamientos (experimental y control). Las cámaras experimentales $(n=20)$ contenían larvas del cuarto estadío $(n=80,40=$ normal, 40 = bajo) mientras que las de control $(n=20)$ no. Se evaluó el efecto de la reducción de pozas en la pérdida de masa de las hojas, interacciones agresivas ( $>25 \%$ de su envoltura removida) y mortalidad larval. La reducción en el nivel de las pozas aumentó la pérdida de masa de las hojas (ANOVA: $\mathrm{F}=5,17, \mathrm{p}<0.05$, interacciones agresivas (Chi cuadrado: $\mathrm{x}^{2}=6,24, \mathrm{n}=80, \mathrm{p}<0.05$, y mortalidad larval (Chi cuadrado: $x^{2}=4,51, n=80, p<0.05$. Este estudio muestra la respuesta temprana de un tricóptero tropical a una señal abiótica de un cambio ambiental drástico. Esta investigación contribuye al escaso conocimiento sobre el comportamiento de procesamiento de hojarasca en larvas de tricópteros durante etapas tempranas de reducciones de flujo, como las causadas por sequías.

PALABRAS CLAVE: tricópteros; Phylloicus; reducción nivel de agua; procesamiento hojarasca; quebradas tropicales Puerto Rico 


\section{INTRODUCTION}

Climate change models predict decreases in runoff on different places of the world, which will result in overall lower water levels in streams (Leberfinger et al., 2010). As droughts become more frequent and persistent, it is necessary to document their effects on natural populations and ecosystem function (Boulton, 2003; Leberfinger et al., 2010). Our understanding of the effects of drought on aquatic ecosystems is limited and effects on ecosystem function are unknown (Boulton, 2003; Leberfinger, 2010). Few studies have examined the impact of droughts due to the difficulty in predicting when and where a drought will likely occur (Covich et al., 2003). Most of drought data has been collected as part of ongoing research in freshwater ecosystems designed to address different question when the droughts occurred (Lake, 2003).

The main effect of drought on streams is the reduction of streamflow, water depth, and the fragmentation of stream ecosystems into isolated pools (Lake, 2003; Schlief and Mutz, 2009), which result in reduced habitat availability and water quality for stream communities. Aquatic insect responses to drying are triggered by different cues including wetting and drying events, food availability, temperature, photoperiod, and water chemistry (Lund et al., 2016). These cues influence behaviors (e.g., movement to refuges and tolerance to changing conditions $\left[\mathrm{O}_{2}\right.$, temperature, crowding]) and life cycle events (e.g., egg hatch, larval pupation, emergence, adult flight) that enhance survival and completion of development (Boulton, 2003). Changes in behavior and life cycle events could also influence ecosystem dynamics (e.g. biological interactions, organic matter and nutrients uptake, transformation, and transport; Boulton, 2003; Lake, 2003).

As drought conditions persist and streams dry up, available habitat decreases and invertebrates are limited to pools, resulting in crowding and influence on ecosystem processes through interactions like increased competition (Covich et al., 2003; Leberfinger et al., 2010). In addition, drying of the aquatic habitat may induce insect early emergence, which in turn can affect riparian and terrestrial food webs that rely on energy fluxes derived from aquatic insect emergence (Leberfinger et al., 2010). Droughts influence life history and phenology of aquatic species, larval feeding (Leberfinger et al., 2010), and can promote conspecific aggressive interactions (Lund et al., 2016).
There is scarce information of the relationship between low flows and benthic communities in tropical nonseasonal rainforests (Covich et al., 2003). In Puerto Rico, a drought during 1994 caused several months of record-low flows in the Luquillo Experimental Forest (LEF) (Covich et al., 2003). Aproximate changes in pool mean depth of $4 \mathrm{~m}, 4 \mathrm{~m}$, and $10 \mathrm{~m}$ ( $\pm 1 \mathrm{SE}$ ) occurred in lower, middle and upper stream pools respectively, compared to the previous year (Covich et al., 2003). Isolated pools with reduced water levels occurred and a loss of access to microhabitats by benthic invertebrates was evident (e.g. shrimps Atya lanipes and Xiphocaris elongata mean densities increased significantly per pool area; Covich et al., 2003). In 2015, another severe drought occurred with a noticeable decrease in rainfall $(2035.81 \mathrm{~mm})$ at El Verde Field Station (located within the LEF) when compared to rainfall of the previous year (3194.31 mm) (Luquillo LTER datasets). These changes in rainfall had effects on ecosystem components such as increases in leaf litter input, decreases in streamflow, and macroinvertebrate abundance (Ramírez, 2016). As organic matter processing and decomposition are essential in small streams, (where organic matter derived from terrestrial sources is the main energy source) (Vannote et al., 1980), changes in leaf litter inputs to the streams and in the abundance of stream populations, drastically modify stream ecosystems functioning.

Caddisflies are good model organisms to assess the effects of drought on stream ecosystems. However, few studies have evaluated the effect of water level reduction on aquatic insect ecosystem functioning (Schlief and Mutz, 2009; Leberfinger, 2010) and fewer are conducted with caddisflies (Shama, 2007; Lund et al., 2016). Calamoceratidae larvae play an important role processing leaf litter in streams, making it available to other consumers (Encalada et al., 2010). Phylloicus larvae are shredders that exert an important role in the conversion of leaf litter into secondary production and accelerating the conversion of coarse particulate organic matter into fine particulate organic matter in headwater streams (Encalada et al., 2010; Moretti et al., 2009). Phylloicus pulchrus Flint 1964, is known as a shredder, but a recent study at El Verde Field Station found that P. pulchrus larvae also feed on Telebasis vulnerata (Odonata: Coenagrionidae) eggs as an additional food source (Cardona-Rivera and Ramírez, 2016).

The objectives of this study were to determine the effect of pool level reductions on $P$. pulchrus larval feeding 
and interactions with conspecifics. We expected that if pool water level was reduced, then larval feeding on detritus would decrease as a response to the stress. We also expected that if pool level wasreduced, then larvae would become aggressive and feeding behavior would shift from leaf shredding to conspecific case destruction.

\section{MATERIALS AND METHODS}

\section{Study site}

The Luquillo Experimental Forest (LEF) is located in the northeastern region of Puerto Rico and has elevations up to $1074 \mathrm{~m}$ (McDowell et al., 2012). Despite the slight rainfall seasonality, a drier period is observed during the first part of the year (McDowell et al., 2012). El Verde Field Station (EVFS) within the LEF $\left(18^{\circ} 18^{\prime} \mathrm{N}\right.$, $65^{\circ} 47^{\prime} \mathrm{W}$ ), receives 200 to $300 \mathrm{~mm}$ of mean monthly precipitation, and has mean daily air temperatures from 21.5 to $23.5^{\circ} \mathrm{C}$ (McDowell et al., 2012). Streams are steep, lined with boulders, and with series of pools and riffles (Ramírez, 2015). Riparian vegetation is dominated by Dacryodes excelsa (Burseraceae), Cecropia scheberiana (Moraceae), Guarea guidonea (Meliaceae) and Prestoea acuminata (Arecaceae) (Luquillo LTER, 2015). Buruquena stream is a small headwater stream located in the EVFS in "tabonuco forest" (lower montane rainforest). The stream has sections of big boulders and steep slopes which are characteristic of the region.

\section{Experimental pool level reductions}

Leaf collection and pre-conditioning: Guarea guidonea senescent leaves were collected from the riparian area of Buruquena stream. This species was selected because it is common in the study site and the larvae select the detrital leaves for case building and consumption (Reyes-Torres and Ramírez, unpublished data). Collected leaves were cut in $2.5 \mathrm{~cm}$ squares, oven dried $\left(70{ }^{\circ} \mathrm{C}\right.$ for one hour), weighted, and pre-conditioned in stream water at the laboratory for a week to promote microbial colonization.

Experimental setup: Two stream pool level treatments (normal and low) and two larval treatments (larvae present for experimental and no larvae for control) were simulated (downscaled in an aquarium) (table 1) at the Aquatic Ecology Laboratory at the University of Puerto
Rico, Rio Piedras. Four rectangular plastic aquaria (38 x $53 \mathrm{~cm}, 14 \mathrm{~cm}$ depth) were filled to one third their capacity with aerated stream water (temperature $=$ $\left.23{ }^{\circ} \mathrm{C}\right)$ and ten circular plastic chambers $(10.16 \mathrm{~cm}$ diameter, $5.08 \mathrm{~cm}$ depth) with screen windows (3.8x5.1 $\mathrm{cm}, 0.7 \mu \mathrm{m}$ mesh) were placed inside each aquarium. The normal pool level treatment was based on field measurements of stream water-level depth, using a five month average from February-June, 2016, and the low pool level treatment was established as one third the normal level. Larvae $(n=80)$ from the most abundant instar (fourth, case width $=6.53-12.23 \mathrm{~mm}$, Reyes-Torres and Ramírez, In press) were collected from the stream. Larval case length was measured on site with a ruler and verified in the laboratory under a dissecting microscope and $1 \mathrm{~mm}$ grid paper. Chambers of the experimental treatment $(n=20)$ contained larvae ( $\mathrm{n}=80,40=$ normal, $40=$ low) while chambers of the control treatment $(\mathrm{n}=20)$ did not contain larvae (table 1 ; figure 1) as a control for leaf microbial degradation and leaching. Chambers with larvae and leaf litter followed the natural ratio of abundance (80 larvae per liter of wet leaf litter, wet litter measured with a plastic $1 \mathrm{~L}$ cup) at the stream, thus water level to leaf litter ratio changed between treatments (table 1).

Table 1. Factors of simulated stream pool levels per chamber.

\begin{tabular}{lrr}
\hline Factors per chamber & $\begin{array}{l}\text { Normal } \\
\text { pool level }\end{array}$ & \multicolumn{2}{l}{$\begin{array}{l}\text { pow } \\
\text { pool level }\end{array}$} \\
\hline Larvae & 4 & 4 \\
Leaf litter volume (ml) & 26 & 26 \\
Water level (cm) & 4.4 & 1.5 \\
$\begin{array}{l}\text { Leaf litter (ml): water } \\
\text { level }(\mathrm{cm})\end{array}$ & $6: 1$ & $17: 1$ \\
\hline
\end{tabular}

Larvae were left undisturbed in the chambers for two weeks, then leaves were removed, oven dried for $24 \mathrm{~h}$ at $70{ }^{\circ} \mathrm{C}$, and weighed. Leaf mass loss was calculated with the following formula: Leaf mass loss ( $\mathrm{g}$ ) = initial leaf mass(g)-remaining leaf mass(g). Larvae were photographed and pictures were analyzed using the ImageJ program (Rasband, 1997-2016) to determine conspecific aggressive interactions. An aggressive larval interaction was identified when larvae had more than $25 \%$ of their cases removed. 


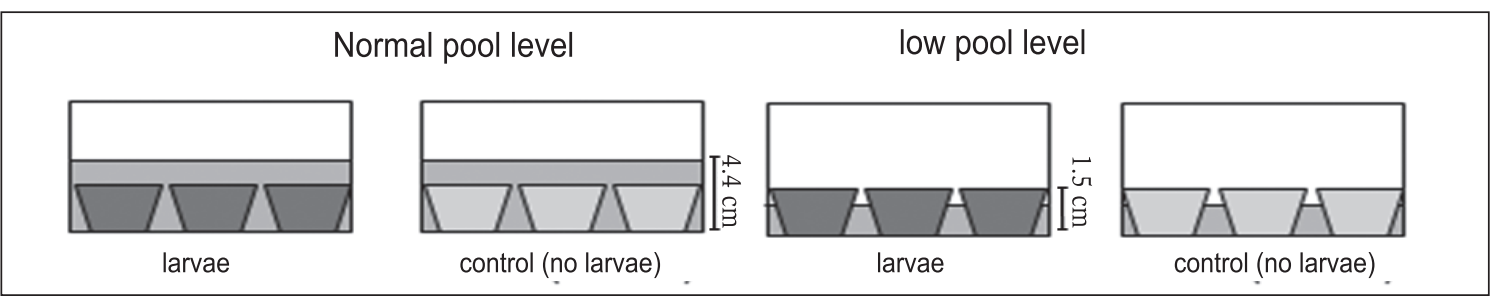

Figure 1. Experimental setup of pool level reduction simulations (frontal view of aquaria). The aquaria were $53 \mathrm{~cm}$ long (not shown in frontal view of figure).

\section{Statistical analyses}

Leaf mass loss data was corrected for non-shredder mass loss (i.e., leaching and microbial processing). A two-way analysis of variance (ANOVA) was performed to determine differences in larval leaf litter processing between the two pool level treatments (normal and reduced). A Chi-square test of independence was performed to examine the relationship between larval interactions and pool level treatments. Another Chisquare test of independence was performed to examine the relationship between larval mortality and pool level treatments. All data analysis was conducted using $\mathrm{R}$ Studio Software (RStudio Team, 2016).

\section{RESULTS}

There was a significant pool level effect on leaf mass loss (ANOVA: $\mathrm{F}=5.17, \mathrm{p}<0.05$. Contrary to expectations, leaf mass loss was significantly higher $(7 \%)$ in the low pool level treatment (figure 2). There was a significant association between larval interaction and pool level treatment (Chi square: $\mathrm{x}^{2}=6.24, \mathrm{n}=80$, $\mathrm{p}$-value $=0.01$ ). Larvae in the low pool level treatment showed higher aggressive interactions (removal of more than $25 \%$ of case) (figure 3). Also, there was a significant association between larval mortality and pool level treatment (Chi square: $\mathrm{x}^{2}=4.51, \mathrm{n}=80$, $\mathrm{p}$-value $=0.03$ ) with higher mortality in the low pool level treatment (figure 4).

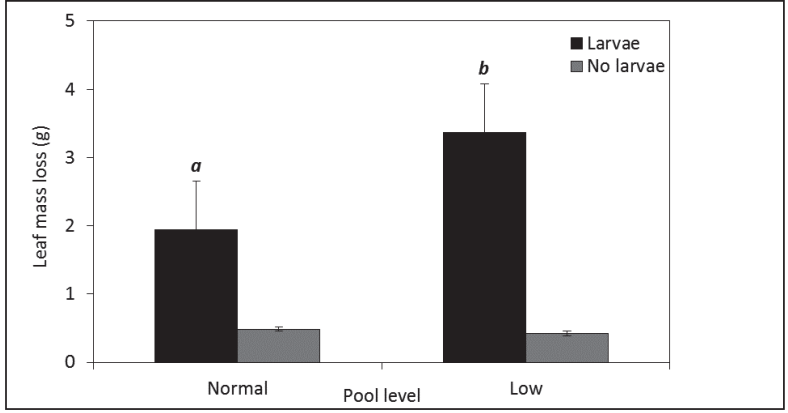

Figure 2. Leaf mass loss (g) between pool level treatments. Data corrected for non-shredder caused mass loss (leaching and microbial processing). Different letters denote significant leaf mass loss differences in larval treatments between pool levels (ANOVA: $\mathrm{F}=5.17, \mathrm{p}<0.05$.

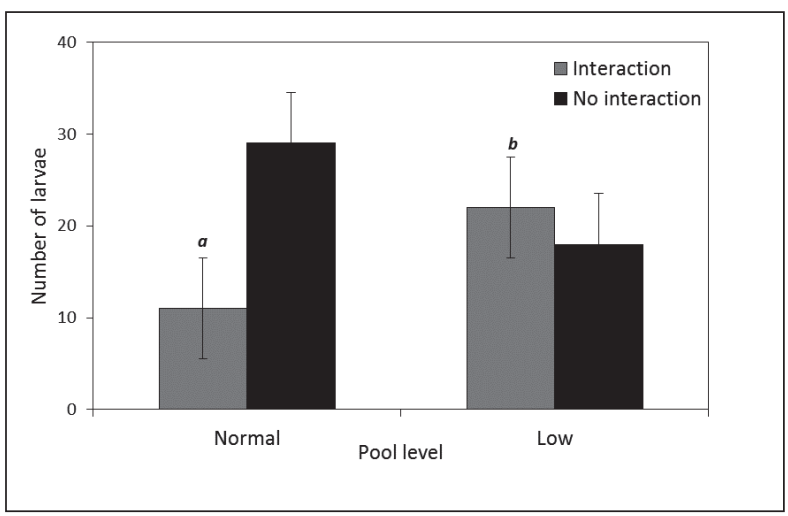

Figure 3. Larval interactions ( $>25 \%$ removal of case) by pool level treatment. Different letters denote significant differences in larval interaction between pool levels(Chi square: $\mathrm{x}^{2}=6.24, \mathrm{n}=80, \mathrm{p}<0.05$ 


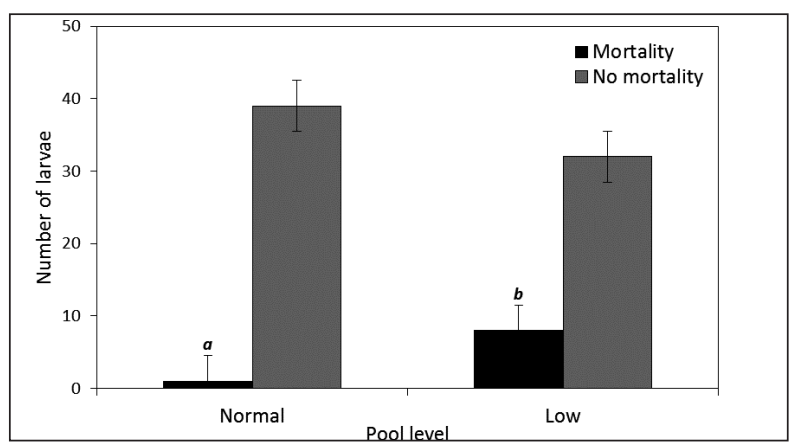

Figure 4. Larval mortality in the two pool level treatments. Different letters denote significant differences in larval interaction between pool levels (Chi square: $x^{2}=4.51$, $\mathrm{n}=80, \mathrm{p}<0.05$ )

\section{DISCUSSION}

Pool level treatment had a significant negative effect on $P$. pulchrus larval feeding and case building. We expected larval feeding to decrease as a response to the stress caused by reduced pool level, as larval energy would probably shift from feeding and case building (expressed by a reduction in leaf mass) to escape mechanisms (e.g. pupation for earlier emergence from the stressful environment, Leberfinger, 2010; Lund et al., 2016, or as a result of larval mortality). Contrary to expectations, low pool levels increased leaf mass loss. This result could be caused by the short duration (two weeks) of the experiment. During this early level reduction state, the stressed larvae could be consuming and storing the necessary energy for molting to the last instar and pupation (Shama, 2007; Leberfinger, 2010).

A longer experimental time may have produced the expected results. Stressed larvae would initially remove more material for consumption and case building (as observed here), but as time passed, pupation and higher larval mortality would result in lower leaf mass loss in comparison to normal pool level treatments. Because the fourth instar larvae takes approximately 21 days to develop and molt (Reyes-Torres and Ramírez, in press), and the experiment was run for only two weeks, we propose that not enough time was given for the larvae to reach the final instar and pupate, and for the pool conditions to pose a harder threat to the larvae. An experiment run for six weeks (as opposed to the two weeks of this experiment) reported lower leaf mass loss as drought increased for two Limnephilidae shredders (Limnephilus bipunctatus and Limnephilus flavicornis) common in intermittent streams (Leberfinger, 2010). Another study found that permanent stream and shredder caddisfly Asynarchus nigriculus (Limnephilidae) had lower growth rates when stressed by hydroperiod (Shama, 2007). Both studies showed pupation induced by drought (Shama, 2007; Leberfinger, 2010), which we did not observe for the probable reasons mentioned above. This research can complement other studies (e.g. Shama, 2007; Leberfinger, 2010) by shedding light on caddisfly larvae leaf litter processing on early stages of prolonged droughts.

Species responses to flow reductions are different by regions (i.e., tropical vs. temperate) and between habitats (e.g., temporary ponds, intermittent and perennial streams). Species from temperate regions, intermittent streams and temporary ponds can respond to changing and harsh conditions more efficiently as they are adapted (e.g. life-history schedules, physiological mechanisms and behaviors) to drastic habitat variations (Lake, 2003; Shama, 2007; Leberfinger, 2010). Alternatively, species from permanent streams may take longer times to incur in adjustments, or have higher mortality rates (Lake, 2003; Shama, 2007). Thus species from perennial tropical streams are less resistant and encounter higher pressures during drastic habitat variations than their temperate counterparts (Lake, 2003), as they are adapted to low seasonality and more stable biotic and abiotic conditions (Boulton, 2003; Jacobsen et al., 2008). Phylloicus pulchrus larvae showed higher aggressive interactions (removal of more than $25 \%$ of case) in treatments with low pool levels. As expected, reduction of pools prompted larval aggressive behaviors (i.e., conspecific case destruction), as a result of larval crowding. This interaction is probably intentional to decrease larval numbers in a limited space (limited 0 ) as leaf litter was not limited. These results are similar to those of Lund et al. (2016) where lower water levels and higher larval densities increased the number and duration of shredder A. nigriculus (Limnephilidae) larval encounters and larval predation (cannibalism).

Carnivory in detritivores may provide a high-energy, high-protein food supplement to their diet enhancing their nutrition and development (Cardona-Rivera and Ramírez, 2016; Lund et al., 2016). This supplementation has been reported in late instar shredding caddisflies (Anderson, 1976; Giller and Sangpradub, 1993). As previously mentioned, there is evidence of $P$. pulchrus larvae feeding on Coenagrionidae (Odonata) eggs (Cardona-Rivera and Ramírez, 2016). Also protein supplemented diets accelerated development and 
pupation in A. nigriculus (Lund et al., 2016). Overall, low pool levels and larval crowding may induce changes in tropical shredder caddisflies feeding and conspecific behavior.

Invertebrates can be eliminated or significantly reduced from streams during water level reductions (Lake, 2003). Higher $P$. pulchrus larval mortality in low pool level treatments may be a result of accumulated detritus and low oxygen levels. Stagnant, low oxygenated waters with toxic build-up of leachates may occur in such areas, killing the majority of invertebrates (Lake, 2003). In this experiment low pool level treatments had oxygenated water by air pumps but no water circulation or filtering (water level too low for the filter), which may had caused lower oxygen levels. This research provides evidence of the early response of a tropical caddisfly to an abiotic cue (level reduction) in a changing environment. It is important to understand the effects of drying streams in their biota to comprehend how stream ecosystems function and will respond to such changes. With this study we contributed to the knowledge on the effect of water level reduction on tropical stream species and their response; specifically a caddisfly with an important role in stream leaf litter processing.

\section{ACKNOWLEDGEMENTS}

We acknowledge Patina Méndez for her comprehensive feedback and encouragement throughout the research and manuscript completion.

\section{REFERENCES}

Anderson, N. H. 1976. Carnivory by an aquatic detritivore, Clistoronia magnifica (Trichoptera: Limnephilidae). Ecology 57: 1081-1085.

Boulton, A. J. 2003. Parallels and contrasts in the effects of drought on stream macroinvertebrate assemblages. Freshwater Biology 48(7): 1173-1185.

Cardona-Rivera, G. A. and Ramírez, A. 2016. Predation of Telebasis vulnerata (Odonata: Coenagrionidae) eggs by detritivorous caddisfly larva, Phylloicus pulchrus (Trichoptera: Calamoceratidae). International Journal of Odonatology 19(4): 253-256.

Covich, A.P., Crowl, T.A. and Scatena, F.N. 2003. Effects of extreme low flows on freshwater shrimps in a perennial
Encalada, A. C., Calles, J., Ferreira, V., Canhoto, C. M. and Graca, M. A. S. 2010. Riparian land use and the relationship between the benthos and litter decomposition in tropical montane streams. Freshwater Biology 55: 1719-1733.

Giller, P. S. and Sangpradub, N. 1993. Predatory foraging behavior and activity patterns of larvae of two species of limnephilid cased caddis. Oikos 67: 351-357.

Jacobsen, D., Cressa, C., Mathooko, J. and Dudgeon, D. 2008. Chapter 4: Macroinvertebrates: Composition, Life Histories and Production. In: Dudgeon, D. Editor. Tropical Stream Ecology. Elsevier, Netherlands.

Lake, P. S. 2003. Ecological effects of perturbation by drought in flowing waters. Freshwater Biology 48: 1161-1172.

Leberfinger, K., Bohman, I. and Herrmann, J. 2010. Drought impact on stream detritivores: experimental effects on leaf litter breakdown and life cycles. Hydrobiologia 652: 247-254.

Lund, J., Wissinger, S. and Peckarsky, B. 2016. Caddisfly behavioral responses to drying cues in temporary ponds: implications for effects of climate change. Freshwater Science 35(2): 619-630.

Luquillo Long Term Ecological Research. 2015. Setting._ URL:_http://luq.lternet.edu/content/setting. Accesed: March 17, 2017.

McDowell, W. H., Scatena, F. N., Waide, R. B., Brokaw, N., Camilo, G. R., Covich, A. P., Crowl, T. A., González, G., Greathouse, E. A., Klawinski, P., Lodge, D. J., Lugo, A. E., Pringle, C. M., Richardson, B. A., Richardson, M. J., Schaefer, D. A., Silver, W. L., Thompson, J., Vogt, D. J., Vogt, K. A., Willig, M. R., Woolbright, L. L., Zou, X. and Zimmerman, J. 2012. Geographic and Ecological Setting of the Luquillo Mountains. In: Brokaw, N., Crowl, T. A., Lugo, A. E., McDowell, W. H., Scatena, F. N., Waide, R. B., Willig, M. R. Editor. A Caribbean Forest Tapestry, The multidimensional nature of disturbance and response. Oxford University Press, New York.

Moretti, M. S., Loyola, R. D., Becker, B. and Callisto, M. 2009. Leaf abundance and phenolic concentrations codetermine the selection of casebuilding materials by Phylloicus sp. (Trichoptera, Calamoceratidae). Hydrobiologia 630(1): 199-206.

Ramírez, A. 2015. Streams. Luquillo LTER._URL:_from http://luq.lternet.edu/streams-alonso-Ramírez. Accesed March 17, 2017. 
Ramírez, A. 2016. Entre sequías y huracanes, y ahora cambio climático: La complicada vida de los macroinvertebrados en el Caribe. Oral presentation: Tercer Congreso Latinoamericano de Macroinvertebrados de Agua Dulce.

Reyes-Torres, L. J. and Ramírez, A. 2018. Life history and phenology of Phylloicus pulchrus (Trichoptera: Calamoceratidae) in a tropical rainforest stream of Puerto Rico. International Journal of Tropical Biology and Conservation In press.

RStudio Team 2016. RStudio: Integrated Development for R. RStudio, Inc., Boston, MA http://www.rstudio.com/. Accesed March 17, 2017.

Schlief, J. and Mutz, M. 2009. Effect of sudden flow reduction on the decomposition of alder leaves (Alnus glutinosa [L.] Gaertn.) in a temperate lowland stream: a mesocosm study. Hydrobiologia 624(1): 205-217.

Shama, L. 2007. Population persistence in temporary streams: plasticity and gene flow in an alpine caddisfly. Doctoral Thesis, Swiss Federal Institute of Technology Zürich, Zürich, Switzerland.

Springer, M. 2010. Macroinvertebrados de Agua Dulce de Costa Rica I, Capítulo 7: Trichoptera. Revista de Biología Tropical 58(4): 151-181.

Vannote, R.L., Minshall, G.W., Cummins, K.W., Sedell, J.R. and Cushing, C.E. 1980. The river continuum concept. Canadian Journal of Fisheries and Aquatic Sciences 37(1): 130-137.

Fecha de recepción: 09/10/2017

Fecha de aceptación: 06/03/2018

Publicado en línea: 06/03/2018

Para citar este artículo: Reyes-Torres, L.J. and Ramírez, A. 2018. Effects of experimental pool level reduction on Phylloicus pulchrus (Trichoptera: Calamoceratidae) feeding and conspecific behavior from a tropical rainforest stream. Intropica 13(1): 13-19. DOI: http://dx.doi.org/ 10.21676/23897864.2352 